\begin{tabular}{|c|c|c|}
\hline \multirow{2}{*}{\multicolumn{2}{|c|}{\begin{tabular}{l|l} 
DE & DE GRUYTER \\
OPEN &
\end{tabular}}} & ECONOMIC THEMES (2017) 55(4): 501-519 \\
\hline & & DOI 10.1515/ethemes-2017-0028 \\
\hline
\end{tabular}

\title{
ANALYSIS OF DISTRIBUTION CHANNELS' SUCCESSFULNESS -THE CASE OF THE RETAIL CHAINS IN THE REPUBLIC OF SERBIA
}

\author{
Aleksandra Anđelković \\ University of Nis, Faculty of Economics, Republic of Serbia \\ $\square$ aleksandra.andjelkovic@eknfak.ni.ac.rs \\ Nada Barac \\ University of Nis, Faculty of Economics, Republic of Serbia \\ \nada.barac@gmail.com \\ Marija Radosavljević \\ University of Nis, Faculty of Economics, Republic of Serbia \\ $\triangle$ marija.radosavljevic@eknfak.ni.ac.rs
}

UDC

$339.187 .4(4$

97.11)

Original scientific paper

\begin{abstract}
The importance of distribution channels comes from the increasingly sophisticated consumer demands, producer's focus on core competences, and the contribution of the distribution channels to achievement of goals at the national economy level. Due to the fact that intermediaries of distribution channel have the role to link producer and consumers, the results of their functioning have a direct impact on the mentioned partners in the channel. Therefore, the efficiency of the intermediaries directly affects the performance of related partners, producers and consumers. Retailers, as intermediaries in the channel, attracted great attention due to their leadership position and power, which proceed from direct communication with consumers. In this regard, the objective of the research presented in this paper is the analysis of the importance of distribution channels, from partners' point of view, as well as from macro aspect, with special reference to the retailers, as the primary participants in the distribution channel, in the Republic of Serbia. As indicators of performance, authors use Return of Sale (ROS) and Return of Equity (ROE). By applying the regression analysis, the authors examine whether the performance and role of retail chain leaders in distribution channels depends on the size of the sales network, or the number of sales facilities. The survey shows that the largest retail chains in the Republic of Serbia are performing below the average for the retail sector, and that the size of their retail network has a significant impact on the achieved results.
\end{abstract}




\section{Received:} 30.10.2017.

Accepted:

Keywords distribution channels, retail chains, LPI, ROS, ROE.

20.12 .2017

\section{Introduction}

Distribution channels are interorganisational networks, or super organisations. They could be described as pathways for providing product flows from producers to consumers. Distribution channels represent network of partners between producers to consumers including various intermediaries like wholesalers and retailers, showing the route of moving goods from producers to industrial users or consumers. The purpose of distribution channels is overcoming the gap (Singh, 2016a) between place of production and place of consumption, by creating time, place, and possession utilities (Aličić, Duman, 2013). Bering this in mind, it can be said that distribution channels are networks of interdependent entities, which are responsible for performing multiple activities, processes and tasks, with purpose to provide adequate services or products to the market (Rosenberg, 1974).

Designing and managing the relations among partners represents one of the factors of their competitiveness. Design of distribution channels depends on countries and industries, but all distribution channels could be described with following characteristics: directness, levels, density, variety, and novelty (Mulky, 2013, 180; Singh, 2016). Directness implies direct contact between producers and consumers without involving intermediaries (Rushton et al., 2010; Andrejić, 2015). Distribution channels could be short or direct, but also could be long or indirect, depending on different reasons and factors, such as characteristics of market, consumers, products or raw materials, relations between partners in the channel and etc. Channel's levels depend on the number of different buying and selling partners, which exist among producer and consumers. For example, in the air industry between producer and customer or airplane companies there is no distributor; in automotive industry, producers sell products through exclusive dealers, but Fast-moving consumer goods (FMCG) which require a higher number of levels and distribution channels for this type of products could include wholesaler and retailer between producer and consumers (Mulky, 2013). Density depends on the number of sales facilities within some geographic area. Thus, distribution through the fewer number of sales facilities represents exclusive distribution, while distribution through the great number of sales facilities represents intensive distribution. Variety of distribution channels refers to the number of different types of sales facilities, while novelty includes using of new types of channels (Singh, 2016, 521). 
Distribution channels design depends on costs, sales volume, expected profits and etc. So factors which need to be analysed before designing distribution channels are (UKessays, 2015):

- Characteristics of market (consumer or industrial market, number and location of buyers, size of order, consumers buying habits),

- Characteristics of product (unit value, perishability, bulk and weight, standardisation, technical nature, product line, age of the product),

- Characteristics of intermediaries (availability, attitudes, services, sale potential, cost),

- Characteristics of company (nature, size, aims, politics of company).

Also, distribution channel design depends on the level of economic development. One study showed that the channels from developed countries have greater number of partners or distributes but fewer levels compared to channels from undeveloped and transition countries (Olson, Granzin, 1992; Mulky, 2013; Singh, 2015, 522). Also, the same study confirmed that channels from undeveloped and transition countries are characterised by unorganised distributes, smaller, independent retailers and wholesalers, insufficient level of information technology implementation, low level of Internet penetration and poor implementation of laws and regulations (Mulky, 2013, 180).

Figure 1 shows different position (quintiles) which countries can reach according to the Logistics Performance Index (LPI) scores. The countries with the lowest LPI scores belong to bottom quantile, while the top quantile is reserved for countries with the highest LPI scores. In the past four quantiles were identified (The International Bank for Reconstruction and Development/The World Bank, 2016):

- Logistics-unfriendly for countries with the lowest LPI scores and logistics performances, or bottom LPI quintile;

- Partial performers where belong countries with some logistics constraints (often in countries with low and middle-income) or the third and fourth LPI quintiles;

- Consistent performers for countries with better performance of logistics activities than countries from previous quantile or second LPI quintile;

Logistics-friendly for countries with the highest LPI scores and with the most high income or top LPI quintile. 
Figure 1. Quantile of LPI scores

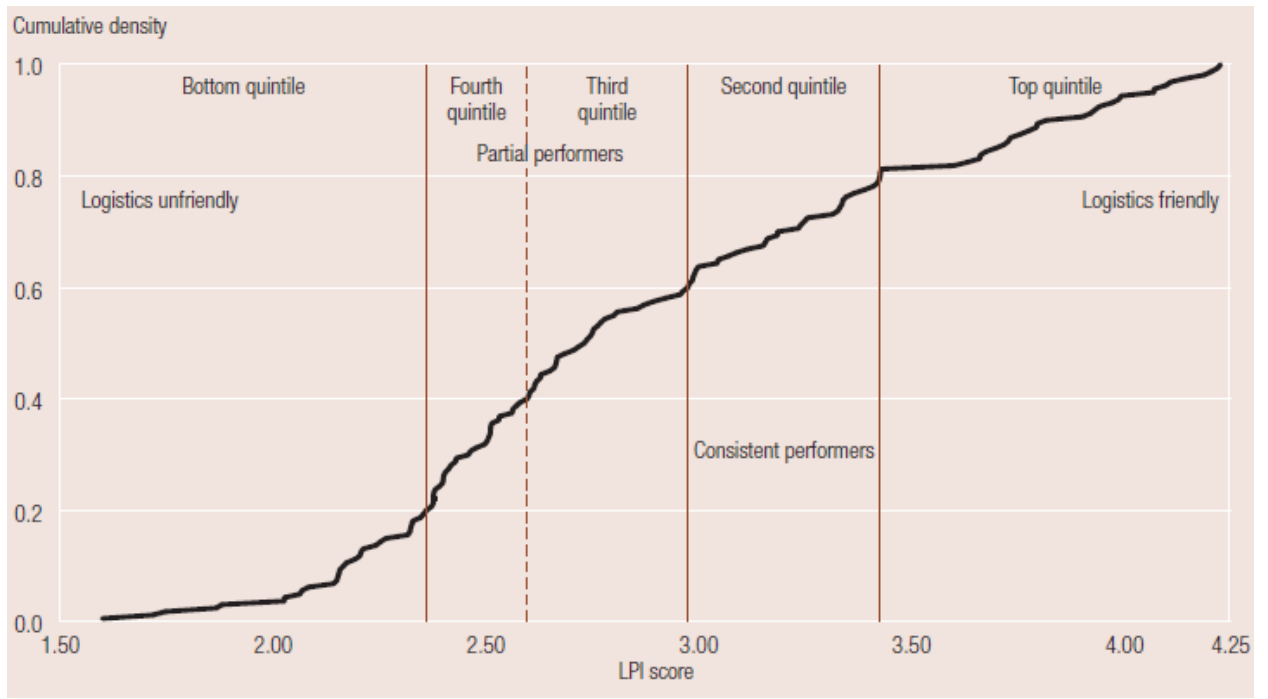

Source: The International Bank for Reconstruction and Development/The World Bank, 2016.

In the document Connecting to Compete: Trade Logistics in the Global Economy scores for the six components (Customs, Infrastructure, Ease of shipping arrangements, Quality of logistics services, Tracking and tracing, and Timeliness) from four LPI surveys were used to generate a bigger picture to indicate countries' logistics performance more accurately. This approach reduces random variation from one LPI survey to another and enables the comparison of 167 countries. Each year's scores in each component were given weights: 6.7 percent for 2010, 13.3 percent for 2012, 26.7 percent for 2014, and 53.3 percent for 2016 (the International Bank for Reconstruction and Development/the World Bank, 2016). LPI could be used as an indicator of the degree of development of the trade sector, given the fact that it includes components that could effect on the trade efficiency. According to this index, the Republic of Serbia was in the fourth quantile in 2016 with score of 2.49 (The World Bank), as a country with some logistical constraints.

Complexity of managing is a great problem of today's distribution channels. As distribution channel is network of different entities, managers need to answer the question about setting goals, plans and performances at the level of channel. In addition, problems are allocations of resources, functions and achieved among partners, choosing an adequate strategy, developing a high level of coordination and trust thought distribution channel and etc (Frazier, 1999). Since they include a lot of partners, distribution channels must operate in an integrated way. The idea of the paper is to point to the importance of distribution channels and intermediaries between producers and consumers, especially at the consumer goods market. In 
this sense, the authors analyse the performance of retailers in order to determine the position of the retail sector in the Republic of Serbia. The authors, also, examine the possibility that the number of retail objects has influence on the retail chain performances and point to some limitations of the research, highlighting recommendations for researches that will be carried out in future.

\section{Importance of distribution channels}

There are two aspects of final product distribution: physical distribution channel and trading (transaction) channel (Rushton et al., 2010, 50). Physical distribution channel implies all logistical activities and processes whose realisation ensures the launch of final products from the place of production to the place of consumption. On the other hand, the trading (transaction) channel refers to non-physical activities concerning in placing products from producers to consumers. Distribution channels are very important because they provide the following (Andrejić, 2015, 22):

- Products availability at the market,

- Cooperation and collaboration into network,

- Concentration of companies according to core activities,

- Appropriate level of service,

- Minimum of logistic and total costs,

- Exchanging accurate and reliable information in direct and reverse flows,

- Transactional efficiency as a result of reduced number of connections and activities.

Distribution channels represent a way of overcoming differences in space, time, quality, and quantity, between the place of production and the place of consumption. Also, through distribution channels there are different flows: products, information, and finance flow. Table 1 shows combination of flows and gaps inside distribution channels.

Table 1. Distribution channels flows

\begin{tabular}{|c|c|c|c|c|}
\hline \multirow{2}{*}{ Flows } & \multicolumn{4}{|c|}{ Gaps } \\
\hline & Space & Time & Quantity & Quality \\
\hline \multirow[b]{2}{*}{$\begin{array}{l}\text { Production } \\
\quad \text { flows }\end{array}$} & \multicolumn{4}{|c|}{ Moving products from the place of production to the place of consumption } \\
\hline & $\begin{array}{l}\text { Moving from the } \\
\text { place of production } \\
\text { to the place of } \\
\text { consumption }\end{array}$ & $\begin{array}{l}\text { Keeping } \\
\text { inventory }\end{array}$ & $\begin{array}{l}\text { Consolidation } \\
\text { activities }\end{array}$ & $\begin{array}{l}\text { Changes in the } \\
\text { nature of the } \\
\text { product }\end{array}$ \\
\hline \multirow{2}{*}{$\begin{array}{l}\text { Finance } \\
\text { flows }\end{array}$} & \multicolumn{4}{|c|}{$\begin{array}{c}\text { Transfer finance flows from the place of consumption to the place of } \\
\text { production }\end{array}$} \\
\hline & Transfer payments & $\begin{array}{c}\text { Financing in } \\
\text { advance }\end{array}$ & $\begin{array}{l}\text { Collection and } \\
\text { distribution of }\end{array}$ & Safety of flows \\
\hline
\end{tabular}




\begin{tabular}{|c|c|c|c|c|}
\hline & \multicolumn{2}{|c|}{} & payments & \\
\hline \multirow{3}{*}{$\begin{array}{c}\text { Information } \\
\text { flows }\end{array}$} & \multicolumn{2}{|c|}{ Transfer information flows between all partners in distribution channel } \\
\cline { 2 - 5 } & $\begin{array}{c}\text { Transfer from point } \\
\text { to point }\end{array}$ & $\begin{array}{c}\text { Collection, } \\
\text { storage and } \\
\text { planning }\end{array}$ & $\begin{array}{c}\text { Collection and } \\
\text { distribution }\end{array}$ & $\begin{array}{c}\text { Interpretation, } \\
\text { addition, } \\
\text { processing }\end{array}$ \\
\hline
\end{tabular}

Source: Andrejić, 2015, 23.

Through reducing transactional costs and providing purchasing for the consumers, distribution channels enable enhancing of sales, cash flows, and profitability (Singh, 2016a). An efficient distribution system can help the sustainable development of countries (Fayaz, Azizinia, 2016). The role of intermediaries in process of socio-economic development is reflected in (Lovreta et al., 2015):

- Contribution to creating gross domestic product and national income,

- Influence on personal consumption and living standards,

- Reduction of unemployment - distribution channels are way of reducing unemployment, at the level of economy (Singh, 2016a).

Table 2. Statistical data about distribution channels in the Republic of Serbia

\begin{tabular}{|c|c|c|}
\hline Year & $\begin{array}{c}\text { \% of wholesale and retail trade } \\
\text { in relation to the total number of } \\
\text { companies }\end{array}$ & $\begin{array}{c}\text { \% of employees in wholesale and retail } \\
\text { trade in relation to the total number of } \\
\text { employees in the economy }\end{array}$ \\
\hline 2012 & $35.76 \%$ & 19.33 \\
\hline 2013 & $35.33 \%$ & 13.34 \\
\hline 2014 & $35.1 \%$ & 19.5 \\
\hline 2015 & $34.4 \%$ & 19.7 \\
\hline
\end{tabular}

Source: Chamber of Commerce and Industry of Serbia

Table 2. shows the participation of the number of companies in the field of trade (both wholesale and retail) in the total number of companies in the period 2012 - 2015. In addition, the table shows the contribution of trade in terms of employment.

Distribution channel could be used as a source of strategic advantages for all networked partners. Knowledge, skills and market positioning of wholesalers and retailers, as partners in distribution channels are, the reasons why they provide access at the markets. By performing their tasks, wholesalers and retailers are creating value for both parties, for producers and consumers. By specialising for sales activities, they enable the producers to do what they do the best - to focus on core, production activities (UKessays, 2015). Also, from the producer's point of view, importance of distribution channels comes from fulfilling and creating consumer demand for products and services (Singh, 2016a). Companies specialised 
for producing could have their own — direct-organisation for consumer support, or they could use intermediaries (Goffin, 1999). Many producers do not have enough financial resources, expertise and knowledge for direct distribution. Producers generally make a limited variety of products at the large quantities. At the same time, consumers require a great variety of products at the limited quantity. Therefore, the key role of intermediaries has become more important due to increasingly wider markets and growing complexities of distribution (Singh, 2016a). Producers could be too small or too large for taking responsibility for distributing products directly to the markets. However, distributers, which are specialised for export-import activities, are able to handle complex custom procedures, for few or great number of small producers, and they also have a greater competences for distributing activities, in comparison with producers. Also, distribution channels make easier life to the consumers, by reducing time and money for buying different items. Everything would be more complicated if each consumer is obliged to buy each item at its source (UKessays, 2015).

Selection of distribution channels is very important process for each company, especially because efficiency of distribution channels has great influence on success of company's operations. Limitations of measuring distribution channels efficiency are: selection of appropriate indicators, level of measuring efficiency, efficiency decomposition, conflicting goals, shared resources etc (Andrejić, Kilibarda, 2016). There are a lot of different indicators of successfulness of distribution channels. One of them is efficiency of distribution channels, which can be improved as a result of cost reduction and increased consumer satisfaction (Andrejić, Kilibarda, 2015). Higher consumer satisfaction could be result of different services of distribution channels, such as (Sellers-Rubio, Mas-Ruiz, 2006, 162):

- Accessibility - possibility of consumers to use services easily,

- Product assortment - availability of great size and length of the product list,

- Assurance of product delivery - availability of products in the required format at space and time when consumer wants them,

- Amount of information - availability of different information to the consumers (about prices, products, services and etc.),

- Ambience - customised ambient to the consumers.

However, as distribution channel consists of many organisations, which differ among themselves in terms of goals, roles, power, access to information, it is logical to expect the appearance of conflicts between partners. Conflicts between partners in distribution channel and their impact on relationships and performances of channel must not be ignored (Frazier, 1999), because relationships between partners in distribution channel are very important for its effective functioning. They are result of trust, commitment, cooperation, coordination and decisions about resource allocation (Mohr, Sohi, 1995). According to the great number of 
authors, conflicts could jeopardise relationships, and, thus, consequently, the efficiency of distribution channels (Rosenberg, 1974; Frazier, 1999; Cunningham, 2013), but influence of conflicts on the each separate partner in distribution channels until today has not significantly analysed. Rosenbloom (1973) defined three types of effects of conflicts in distribution channel on channel efficiency:

- Negative effects - meaning that between conflicts and channel efficiency there is a negative correlation;

- Without effects - meaning unchanged efficiency in spite of conflicts in distribution channel;

- Positive effects - meaning that conflicts in distribution channel are reason for increased efficiency of the channel.

As shown in Figure 2., the levels of conflicts in distribution channel that should be observed when analysing the channel's efficiency are OE and OF. OE represents the level of conflict in channel before partners have taken actions for increasing efficiency. OF is level of conflicts which makes that channel efficiency goes down. So points $\mathrm{E}$ and $\mathrm{F}$ are very important for optimal utilisation of channel resources. Distribution channel manager needs to choose appropriate actions before channel reaches the point $\mathrm{C}$, in order to sustain the level of efficiency reached in point $\mathrm{C}$, with purpose to achieve maximum of channel efficiency. By using an adequate strategy for resolution of conflict among partners in distribution channel, effects at the level of distribution channels efficiency may be accomplished. Channel will be in point $\mathrm{E}$ or $\mathrm{F}$ depending on a way of conflict resolution (Singh, 2015). If things go wrong, and due to the increased conflict, efficiency drops on the level in point $\mathrm{D}$, when $\mathrm{D}$ is above point $\mathrm{A}$, the conflicts in the distribution channel are still welcome.

Figure 2 Conflict-efficiency graph

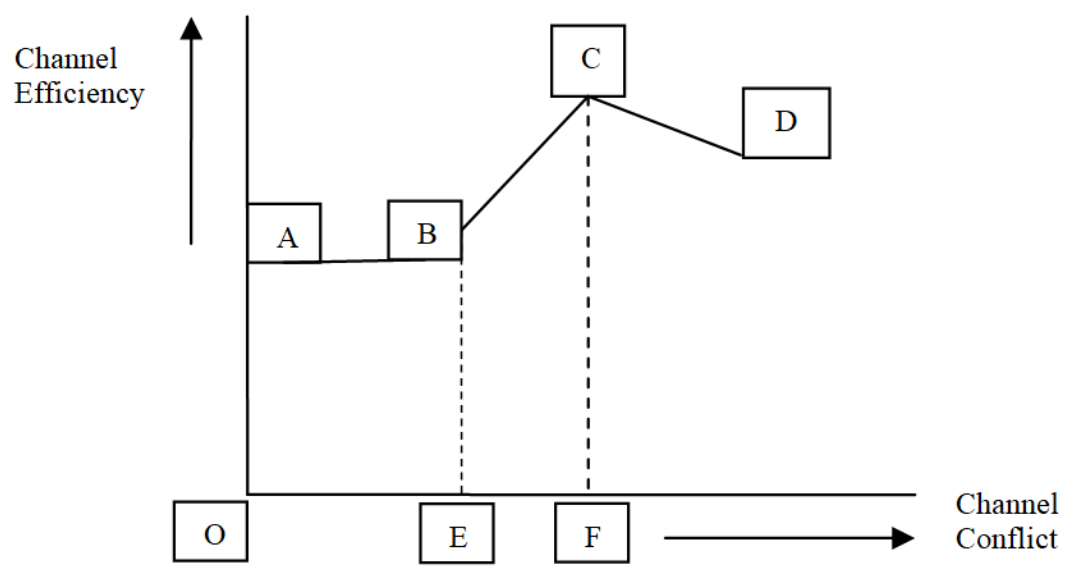

Source: Singh, 2015 
Leaders in the field of distribution use different ways for sustaining their competitive position like competitive pressures, mergers, acquisitions, new product lines and greater consumer expectations and etc. Using by these strategies they become effective, flexible and proactively responsive to the markets requests (Sreenivas, Srinivas, 2008).

\section{Methodology of research}

In focus of analysing of the position and successfulness of the distribution channels in the Republic of Serbia are retailers, as primary participants of channels. The justification of choosing the retailers comes from their domination in distribution channels, compared to other partners, especially in distribution of consumer goods. Due to their size, in terms of number of sales objects, realised revenue of sales, number of employees, market share, they influence decision-making, both at the level of distribution channel, as well as economy as a whole. According to some authors, dominant position of retail chains in distribution channel comes from (Lovreta et al., 2015):

- Concentration and emergence of multifilal retail systems,

- Taking over the functions that are outsourced by (promotion, packaging, product design, etc.),

- Profitability of large retail companies,

- Implementation of information technologies,

- Development of a trade mark.

Since 2008, situation in the retail sector in the Republic of Serbia has changed significantly. The retail sector has been characterised by increase in market concentration, intensifying of inter type competition, and, also, high level of implementation of IT and communication technology.

The analysis presented in this paper includes the 10 largest retail chains in the Republic of Serbia, according to achieved market share. These are retail chains from sector of consumer goods: Idea, Mercator-S, Delhaize, Aman, Gomex, Univerexport, Europrom, Dis, Metro and Veropoulos. Table 3 gives an overview of the mentioned retail chains in terms of number of sales objects and realised revenue of sales in 2016.

Table 3. Retail chains by number of sales objects and revenue of sales

\begin{tabular}{|l|c|c|c|c|}
\hline & $\begin{array}{c}\text { Number of sales } \\
\text { objects }\end{array}$ & $\%$ & $\begin{array}{c}\text { Revenue of sales } \\
\text { (in thousands rsd) }\end{array}$ & $\%$ \\
\hline IDEA & 190 & 18.3 & 2948070 & 1.1 \\
\hline MERCATOR-S & 137 & 13.2 & 98321715 & 35.7 \\
\hline DELHAIZE & 381 & 36.7 & 84342801 & 30.6 \\
\hline
\end{tabular}




\begin{tabular}{|l|c|c|c|c|}
\hline AMAN & 139 & 13.4 & 15308345 & 5.6 \\
\hline GOMEX & 91 & 8.8 & 9404853 & 3.4 \\
\hline UNIVEREXPORT & 42 & 4.0 & 15630740 & 5.7 \\
\hline EUROPROM & 29 & 2.8 & N/A & N/A \\
\hline DIS & 16 & 1.5 & 21857535 & 7.9 \\
\hline METRO & 9 & 0.9 & 23622226 & 8.6 \\
\hline VEROPOULOS & 5 & 0.5 & 4081151 & 1.5 \\
\hline & 1039 & 100.0 & 2948070 & 100.0 \\
\hline
\end{tabular}

Source: Republic of Serbia, Ministry of Trade, Tourism and Telecommunications, Database of Trade Companies and Entrepreneurs; The Serbian Business Registers Agency

For analysing successfulness of distribution channels, authors used different inputs and outputs. Relying on the research of Sellers-Rubio and Mas-Ruiz (2006), authors used sales revenue and profit as outputs, and the number of retail objects and capital as inputs. Beside the fact that mentioned authors in the analysis included the number of employees as input, in this research this input is not used. The number of employees is neglected due to the fact that the reports of the observed companies include the data about all employees, and not only the ones that are directly involved in the retailing.

Based on the mentioned inputs and outputs, collected from the financial reports of the analysed retail chains, available on the Business Register Agency website, authors have calculated indicators return on sales (ROS) and return on equity (ROE) in the five-year period (2012-2016). In this way, the authors have evaluated the success of the retail chains in the Republic of Serbia, in the observed period. All companies which are subject of analyses compete in the sector of distribution of consumer goods. Because of similarity of range product between analysed retail chains, the authors assumed that range of products was not a factor of successfulness and profitability of retail chains. As dominant factor of retail chain successfulness, authors point out the number of objects in the sales network of each retailer. The number of objects in the company's sales network is certainly significant. However, the question is: Is the number of sales objects the factor of retail chain performances? In order to answer the question, the authors used regression analysis and defined following hypothesis:

$\mathrm{H}$ : Network of sales objects, in terms of number of objects, influences the difference in ROE between retailers.

Comparing these parameters is justified by indicator All Commodity Volume (ACV) which is used for analysing channel distribution efficiency. ACV represents the total annual sales aggregated from individual sales objects (Reibstein, Farris, 1995, 192; Basker, 2016, 309). In order to test this hypothesis, authors used regression analysis. 


\section{Discussion of research results}

As already mentioned, the indicators used in the analysis of retail chains performance in the Republic of Serbia are ROS and ROE. ROS presents indicator of company's operations efficiency; also known as a profit margin of the company and it's calculated as relation of profit to the realized sales (Carton, Hofer, 2006, 87). The profit margin depends on sector to which the company belongs, for example:

- Trading companies have a low profit margin, usually up to 5\%.

- Production companies have a medium profit margin, usually from 5\% to $15 \%$.

- Highly profitable companies (for example IT and telecommunications companies, pharmaceuticals companies and etc.) usually have a profit margin that is more than $15 \%$.

For example, Walmart is the largest retailer, but profit margin of this company in 2014 was only 3\% (Investopedia(a)). Low profit margin for the retail sector comes from the fact that the Internet has made easier the comparison of prices between retailers and shopping from around the world. Besides that, there is a relatively high price elasticity of demand for retail goods (D'Arcy et al., 2012). That is the reason why it is very difficult for retailers to raise prices. If a company has a net loss, the ratio will be negative.

Table 4 shows that four from the number of analysed retailers are faced with negative ROS, in period 2012-2016. The average ROS for 10 retail chains in the Republic of Serbia in the analysed period is $-1 \%$. This result indicates on unenviable position of the retail sector in terms of business performance. Europrom is the only company that in the analysed period achieved average ROS, as characteristic of the retail sector.

Table 4. ROS

\begin{tabular}{|l|c|c|c|c|c|}
\hline & 2016 & 2015 & 2014 & 2013 & 2012 \\
\hline IDEA & $-79 \%$ & $-33 \%$ & $-8 \%$ & $-4 \%$ & $-8 \%$ \\
\hline MERCATOR-S & $-2 \%$ & $0 \%$ & $0 \%$ & $1 \%$ & $-1 \%$ \\
\hline DELHAIZE & $2 \%$ & $4 \%$ & $4 \%$ & $5 \%$ & $-18 \%$ \\
\hline AMAN & $1 \%$ & $1 \%$ & $1 \%$ & $3 \%$ & $2 \%$ \\
\hline GOMEX & $1 \%$ & $2 \%$ & $2 \%$ & $3 \%$ & $3 \%$ \\
\hline UNIVEREXPORT & $1 \%$ & $0 \%$ & $1 \%$ & $2 \%$ & $3 \%$ \\
\hline EUROPROM & N/A & $6 \%$ & $5 \%$ & $5 \%$ & $5 \%$ \\
\hline DIS & $2 \%$ & $3 \%$ & $4 \%$ & $4 \%$ & $4 \%$ \\
\hline METRO & $-1 \%$ & $-2 \%$ & $-7 \%$ & $-2 \%$ & $-1 \%$ \\
\hline VEROPOULOS & $4 \%$ & $2 \%$ & $1 \%$ & $3 \%$ & $3 \%$ \\
\hline
\end{tabular}

Source: Authors' calculation according to companies' financial reports from The Serbian Business Registers Agency 
ROE is an indicator that shows degree of capitalisation of equity (Berzkalne \& Zelgalve, 2014). ROE at the level of $10 \%$ is considered as a good result that assumes coverage of all capital costs (Investopedia). Companies with losses have a problem with evaluating ROE. When net income is negative, ROE must be negative, too. But it does not mean that negative ROE always presents bad investment. $^{1}$

Negative ROE is the indicator that shareholders of the company are losing, rather than gaining, value. Also, negative ROE could be a reason for investors and partners to avoid investing their money in that company. But, if some investors and partners expect long-term growth in following years, they can make decision about investing or collaborating regardless of negative ROE in the current year. This because reasons for negative ROE could be very high costs of start-ups, including capital expenditures - investments in equipment and other assets, economic crisis and recessions as a consequence of reduced demand and etc (The Finance Base).

Table 5 shows that four from ten retailers in the last five years, at least once were faced with a negative ROE. The average ROE of all analysed companies in the last five years is positive and amounts to 3\%. Metro and Idea are the only companies with negative ROE in all analysed years.

Table 5. ROE

\begin{tabular}{|l|c|c|c|c|c|}
\hline & 2016 & 2015 & 2014 & 2013 & 2012 \\
\hline IDEA & $-103 \%$ & $-24 \%$ & $-140 \%$ & $-44 \%$ & $-54 \%$ \\
\hline MERCATOR-S & $-9 \%$ & $2 \%$ & $0 \%$ & $2 \%$ & $2 \%$ \\
\hline DELHAIZE & $3 \%$ & $6 \%$ & $7 \%$ & $11 \%$ & $-42 \%$ \\
\hline AMAN & $7 \%$ & $11 \%$ & $18 \%$ & $44 \%$ & $31 \%$ \\
\hline GOMEX & $13 \%$ & $22 \%$ & $25 \%$ & $37 \%$ & $42 \%$ \\
\hline UNIVEREXPORT & $5 \%$ & $2 \%$ & $4 \%$ & $9 \%$ & $12 \%$ \\
\hline EUROPROM & N/A & $33 \%$ & $31 \%$ & $36 \%$ & $46 \%$ \\
\hline DIS & $346 \%$ & $12 \%$ & $15 \%$ & $21 \%$ & $24 \%$ \\
\hline METRO & $-6 \%$ & $-9 \%$ & $-29 \%$ & $-6 \%$ & $-3 \%$ \\
\hline VEROPOULOS & $6 \%$ & $4 \%$ & $2 \%$ & $5 \%$ & $6 \%$ \\
\hline
\end{tabular}

Source: Authors' calculation according to companies' financial reports from The Serbian Business Registers Agency

${ }^{1}$ For example, in 2012 Hewlett-Packard Co. had negative net income of \$ 12.7 billion and ROE was negative $(-51 \%)$. The reason for this was restructuring of company's business. But, on the other hand, free production of cash flows, which present cash that company can generate after spending the money for maintaining or expanding its asset, was positive (\$ 6.9 billion) (Investopedia). By using this indicator, ROE becomes positive. 
In order to test mentioned hypotheses regression analysis has been used. According to the results of regression analysis, which are shown in Table 6, it can be concluded that the research hypothesis should be rejected. Therefore Sig. $>0.05$, precisely 0.108 , shows that sales revenue does not depend on the number of sales objects. If the individual retailers are analysed, it can be seen that Idea, with a large number of sales objects, has a negative financial result, during the analysed period. The explanation for such a trend can be found in Idea's Annual Business Report for 2016 - from 2014 Idea leases some of its sales objects (Annual Business Report for 2016, 2016). However, it has to be noticed that in this analysis instead of ROE, which includes negative values, as dependent variable authors used revenue, to the result has to be accepted with reserve.

Table 6. Regression analysis (No. of objects vs Revenue)

\begin{tabular}{|c|c|c|c|c|c|}
\hline \multirow{2}{*}{} & \multicolumn{2}{|c|}{$\begin{array}{c}\text { Unstandardized } \\
\text { Coefficients }\end{array}$} & $\begin{array}{c}\text { Standardized } \\
\text { Coefficients }\end{array}$ & \multirow{2}{*}{ Sig. } \\
\cline { 2 - 4 } & B & Std. Error & Beta & & \\
\hline No of objects & 167236.156 & 90802.046 & .571 & 1.842 & $\mathbf{. 1 0 8}$ \\
\hline
\end{tabular}

Source: Authors' calculation

For further analysis, since authors wanted to find out can this result be accepted for ROE, too, it has been necessary to make some corrections in the observed data. Precisely, it is necessary to omit the data for certain period of for some companies in order to eliminate the data with negative sign. In doing so, the year 2016 was excluded, as well as three companies Idea, Delhaize and Metro.

The next table shows the significance based on regression analysis, without mentioned data. The result is not quite different, and the conclusion is the same there is not influence of number of objects on ROE.

Table 7. Regression analysis (No. of objects vs ROE)

\begin{tabular}{|c|c|c|c|c|c|}
\hline & \multicolumn{2}{|c|}{$\begin{array}{c}\text { Unstandardised } \\
\text { Coefficients }\end{array}$} & $\begin{array}{c}\text { Standardised } \\
\text { Coefficients }\end{array}$ & \multirow{2}{*}{ Sig. } & \\
\cline { 2 - 4 } & B & Std. Error & Beta & & \\
\hline No of objects & $8.313 \mathrm{E}-5$ & .001 & .030 & .153 & .880 \\
\hline a. Dependent Variable: ROE
\end{tabular}

Source: Authors' calculation

In order to test second hypothesis, the same principles and method have been used. The result is presented in the Table 8. 
Table 8. Regression analysis (Capital vs ROE)

\begin{tabular}{|c|c|c|c|c|c|}
\hline & \multicolumn{2}{|c|}{$\begin{array}{c}\text { Unstandardised } \\
\text { Coefficients }\end{array}$} & $\begin{array}{c}\text { Standardised } \\
\text { Coefficients }\end{array}$ & t & Sig. \\
\cline { 2 - 4 } & $\mathrm{B}$ & Std. Error & Beta & & \\
\hline Capital & $3.019 E-9$ & .000 & .497 & 2.917 & $\mathbf{. 0 0 7}$ \\
\hline a. Dependent Variable: ROE
\end{tabular}

Source: Authors’ calculation

According to the regression analysis the result is opposite for the capital as independent variable. The significance of 0.007 is lower than 0.05 so it can be concluded that there is influence of capital on the ROE as output of the analysis.

Calculation presented in the next table is based on the average values. It confirms the previously mentioned results and enables the authors to make final conclusion that the first hypothesis is not confirmed, while the second one is.

Table 9. Regression analysis (Capital and No. of objects vs ROE)

\begin{tabular}{|c|c|c|c|c|c|}
\hline & \multicolumn{2}{|c|}{$\begin{array}{c}\text { Unstandardized } \\
\text { Coefficients }\end{array}$} & $\begin{array}{l}\text { Standardized } \\
\text { Coefficients }\end{array}$ & $\mathrm{t}$ & Sig. \\
\hline & $\mathrm{B}$ & Std. Error & Beta & & \\
\hline No of objects & .001 & .001 & .415 & .980 & .383 \\
\hline Capital & 4.379E-9 & .000 & .775 & 1.829 & .041 \\
\hline
\end{tabular}

Source: Authors’ calculation

This means that the authors have come to the findings that the important factor for providing positive changes in the ROE is capital, while the number of objects is not of much importance.

\section{Conclusion}

One of the distribution channel's characteristics is taking or handing different activities among the partners within the channel. In that sense, retailers increasingly take over the role of wholesalers or even producers, in terms of packaging or performing final phase of the production process. The analysed retail chains are registered under the business activity code that indicates their primary activity, but this does not mean that they do not achieve income on other grounds (Radosavljević, Borisavljević, 2014). Retail chains could be able to realise some activities instead producers or wholesalers and achieve income on that basis. This could be great limitation in research of authors. 
Considering that the results show that there is no statistically significant correlation between the number of objects and profitability, no matter it is analysed based on revenue of ROE. On the other hand, the second factor that is usually mentioned in the research of the authors from the developed countries, capital is identified as a factor whose influence on ROE is statistically significant.

Unfortunately, according to the data from the financial reports of the 10 largest retailers in the Republic of Serbia, it could be concluded that average ROS and ROE from analysed period were below the average for retail sector. This indicates poor results and unenviable position of the retail sector in the Republic of Serbia. In addition, these results point to the need for investing in technological innovation in order to improve the distribution process, bearing in mind that the success of these intermediators in distribution channels has a great influence on performance of partners without direct contact with the market and consumers.

However, this research has few limitations. Detailed analyses should include influence of individual formats of sales objects on income. Different formats in the sales network structure can have a higher influence on revenue, even if retail chain has a low number of those formats. For example, that could be the case with hypermarkets. They became very attractive for consumers due to changes in consumer habits, their way and frequency of purchase. Because of these reasons they could have a great influence on retailer's income. After 2007 hypermarkets experienced great expansion in the Republic of Serbia. In the period 2007-2008, the number of hypermarkets was increased by $130 \%$ compared to traditional, classic stores.

The limitation of the survey is the non-standardisation of the company's business reports. Companies' business reports do not contain data on the number of sales objects during the analysed period.

The results of the research presented in the paper can serve as the basis for future research on retail chains, as participants in the distribution channel. Recently, business sustainability has been very interesting topic for researchers and practitioners, since economic indicators are considered not sufficient enough for assessing business performance. In this regard, future research should focus on analysing the sustainability of retail chains in the Republic of Serbia, examining the relationship between economic, ecological and social performance

\section{References}

Agencija za privredne register [The Serbian Business Registers Agency], Retrieved from: http://www.apr.gov.rs/, Accessed on: 15 June 2017.

Aličić, A. \& Duman, T. (2013). Comparing the efficiency of distribution methods in home appliance industry. European Journal of Business and Social Sciences, 2 (5), 56-75. 
Andrejić, M. \& Kilibarda, M. (2015). Distribution Channels Selection Using PCA-DEA Approach. International Journal for Traffic and Transport Engineering, 5 (1), 74 81.

Andrejić, M. \& Kilibarda, M. (2016). A framework for measuring and improving efficiency in distribution channels. International Journal for Traffic and Transport Engineering, 6 (2), 137-148.

Andrejić, M. M. (2015). Modeli merenja i unapređenja efikasnosti logističkih procesa distribucije proizvoda [Models for measuring and improving eficiency of logistics processes in product distribution]. Ph.D. Thesis. Faculty of transport and traffic engineering, University of Belgrade.

Basket, E. (2016). Handbook on the Economics of Retailing and Distribution. Cheltenham: Edward Elgar Publishing.

Berzkalne, I. \& Zelgalve, E. (2014). Return on Equity and Company Characteristics: An Empirical Study of Industries in Latvia. Proceedings of The 8th International Days of Statistics and Economics, September 11-13, Prague, Czech Republic, pp. 94-103.

Carton, B. R. \& Hofer, W. Ch. (2006). Measuring Organizational Performance: Metrics for Entrepreneurship and Strategic Management Research. Cheltenham: Edward Elgar Publishing.

Cunningham, M. K. (2013). Reducing channel conflict. Journal of Marketing Development \& Competitiveness, 7 (1), 78-83.

D'Arcy, P., Norman, D. \& Shan, Sh. (2012) Costs and Margins in the Retail Supply Chain. RBA Bulletin, June, 13-22.

Fayaz, R. \& Azizinia, M. (2016). Current challenges in distribution channels of cultural goods and services. Marketing and Branding Research, 3, 75-85.

Frazier, G. L. (1999). Organizing and Managing Channels of Distribution. Journal of the Academy of Marketing Science, 27 (2), 226-240.

Godišnji izveštaj o poslovanju za 2016. godinu [Annual Business Report for 2016], (2016). Beograd: Idea d.o.o.

Goffin, K. (1999). Customer support: A cross-industry study of distribution channels and strategies. International Journal of Physical Distribution \& Logistics Management, 29 (6), 374-398.

Investopedia(a), What profit margin is usual for a company in the retail sector? Retrieved from: http://www.investopedia.com/ask/answers/ 071615/what-profit-margin-usualcompany-retail-sector.asp, Accessed on: 10 May 2017.

Investopedia, Are companies with a negative return on equity (ROE) always a bad investment? Retrieved from: http://www.investopedia.com/ ask/answers/070914/are-companies-negative-return-equity-roe-always-badinvestment.asp, Accessed on: 10 May 2017.

Lovreta, S, Končar, J. \& Petković, G. (2015). Kanali marketinga [Marketing channels]. Belgrade: Faculty of Economics, University of Belgrade.

Mohr, J. J. \& Sohi, S. R. (1995). Communication Flows in Distribution Channels: Impact on Assessments of Communication Quality and Satisfaction. Journal of Retailing, 71 (4), 393-416.

Mulky, A. G. (2013). Distribution challenges and workable solutions. IIMB Management Review, 25, 179-195.

Olson, J. E. \& Granzin, K. L. (1992). Economic development and channel structure: a multinational study. Journal of Macro-marketing, 10, 61-77. 
Privredna komora Srbije [Chamber of Commerce and Industry of Serbia], Retrieved from: http://www.pks.rs/PrivredaSrbije.aspx?id=17\&p=2\&, Accessed on: 10 May 2017.

Radosavljević, G. \& Borisavljević, K. (2014). Opšti pokazatelji stanja i razvoja trgovinske mreže u Šumadiji [General indicators of state and development of the trade network in Sumadija], In Proceedings of Stanje i perspektive ekonomskog razvoja grada Kragujevca [State and Perspectives of the Economic Development of the City of Kragujevac], Kragujevac: Faculty of Economics (pp. 205-219).

Reibstein, D. J. \& Farris, P. W. (1995). Market Share and Distribution: A Generalization, a Speculation, and Some Implications. Marketing Science, 14 (3), 190-202.

Republika Srbija, Ministarstvo trgovine, turizma i telekomunikacije, Baza trgovinskih preduzeća i preduzetnika [Republic of Serbia, Ministry of Trade, Tourism and Telecommunications, Database of Trade Companies and Entrepreneurs], Retrieved from: http://mtt.gov.rs/informacije/baza-trgovackih-preduzeca-i-preduzetnika/, Accessed on: 16 July 2017.

Rosenberg, L. J. (1974). A new approach to distribution conflict management. Business Horizons, 17 (5), 67-74.

Rosenbloom, B. (1973). Conflict and Channel efficiency: Some Conceptual Models for the Decision Maker. Journal of Marketing, 37, (3), 26-30.

Rushton, A., Croucher, P. \& Baker, P. (2010). The handbook of logistics and distribution management. 4th edition, London and Philadelphia: Kogan page.

Sellers-Rubio, R. \& Mas-Ruiz, F. (2006). Economic efficiency in supermarkets: evidences in Spain. International Journal of Retail \& Distribution Management, 34 (2), 155171.

Singh, R. (2015). An Assessment of the Impact of Distribution Channel Conflict on Channel Efficiency - Few Improvised Conceptual Models. In: Sharma, D. \& Borna, S. (Eds.), Proceedings of the Academy of Marketing Science (AMS) Annual Conference. Cham: Springer.

Singh, R. (2016). Sales and Distribution Management: A Practice-Based Approach. 1st edition, New Delhi: Vikas Publishing House PVT Ltd.

Singh, S. (2016a). What is the Role of Channel of Distribution? Retrieved from: http://www.preservearticles.com/2012022923845/what-is-the-role-of-channel-ofdistribution.html, Accessed on: 15 May 2017.

Sreenivas, M. \& Srinivas, T. (2008). Effectiveness of Distribution Network. International Journal of Information Systems and Supply Chain Management, 1 (1), 80-8.

The Finance Base, Significance of Negative Return on Shareholder' Equity, Retrieved from: http://thefinancebase.com/significance-negative-return-shareholders-equity3855.html, Accessed on: 10 May 2017.

The International Bank for Reconstruction and Development/The World Bank (2016). Connecting to Compete: Trade Logistics in the Global Economy. Washington: The World Bank.

The World Bank, Retrieved from: http://data.worldbank.org/ indicator/LP.LPI.INFR.XQ, Accessed on: 15 June 2017.

Ukessays (2015). Effectiveness and Efficiency of Distribution Channels in FMCG. Retrieved from: https:/www.ukessays.com/essays/ marketing/effectiveness-andefficiency-of-distribution-channel-in-fmcg-marketing-essay.php, Accessed on: 10 June 2017 


\section{ANALIZA USPEŠNOSTI KANALA DISTRIBUCIJE - MALOPRODAJNI LANCI U REPUBLICI SRBIJI}

Apstrakt: Značaj kanala distribucije proizilazi iz sve sofisticiranijih zahteva potrošača, fokusa proizvođača na ključne kompetencije, kao i doprinosa kanala distribucije ostvarivanju ciljeva na nivou privrede. S obzirom na činjenicu da posrednici u kanalu distribucije imaju ulogu spone ili veze između proizvođača i potrošača, rezultati njihovog funkcionisanja imaju direktan uticaj na pomenute partnere u kanalu. Dakle, efikasnost posrednika direktno utiče na efikasnost partnera sa kojima su oni povezani, odnosno proizvođača i potrošača. Maloprodavci, kao posrednicima u kanalu, zbog svoje liderske pozicije i moći, koje su rezultat direktne komunikacije sa potrošačima, danas privlače veliki pažnju. U tom smislu, cilj istraživanja prikazanog u radu jeste analiza značaja kanala distribucije, kako sa aspekta partnera unutar kanala, tako i sa makro aspekta, uz poseban osvrt na maloprodavce, kao primarne učesnike kanala distribucije u Republici Srbiji. Kao indikatore uspešnosti, autori koriste indikatore: profitnu stopu i stopu prinosa na kapital. Primenom regresione analize, autori ispituju da li je uspešnost i uloga lidera maloprodajnih lanaca u kanalima distribucije posledica veličine prodajne mreže, odnosno broja prodajnih objekata. Istraživanjem se uočava da najveći maloprodajni lanci u Republici Srbiji ostvaruju performanse ispod proseka za sektor maloprodaje, kao i da veličina njihove maloprodajne mreže nama značajan uticaj na ostvarene rezultate.

Ključne reči: kanali distribucije, maloprodajni lanci, LPI, ROS, ROE.

\section{Authors' biographies}

Aleksandra Anđelković is an Assistant Professor at the Faculty of Economics, University of Nis, for narrow scientific field of business management, for the group of courses Strategic Logistics Management, International Logistics, Marketing Channels, and International Marketing. In 2015, she defended the doctoral dissertation entitled Supply chain risk management for the purpose of increasing its resilience. Until now she was two times a scholar and researcher of the Austrian Agency for International Cooperation in Education and Research, at the University of Vienna (2013), and Vienna University of Economics and Business (2016). Her key interest areas are: strategic management of logistics, international logistics, supply chains, international marketing, and marketing channels. So far, she has published more than 50 papers in journals and proceedings from the conferences (national and international).

Nada Barac is a Full Professor at the Faculty of Economics, University of Nis. She is a member of the following professional bodies: Society of Economists in Serbia and the European Association for Education and Research in 
Commercial Distribution. She has participated in five projects which were financed by the Government of the Republic of Serbia and also was a researcher on project 149052 financed by the Ministry of Science and Environment Protection RS: 2005-2010 and on international projects TEMPUS Project CD_JEP 17019 - 2002, TEMPUS Project CD_JEP_41103 2006, TEMPUS Project CD_JEP 41146 - 2006. Her foreign countries experience includes: LSE London UK, 1985, Otto-von-Guericke-Universität Magdeburg, Lehrstuhl Logistik, IFSL TU Dresden, Fakultät Maschinenwesen Institut für Fördertechnik, Baumaschinen und Logistik TU München, Faculty of Mechanical Engineering, Faculty of Mechanical Engineering (Department of Material Handling, Material Flow and Logistics), Master of Science "International business development" JEP_41103_2006 (Liste des members du consortium groupeecolesuperieure de commerce de Clermont- CCI ClermontFD/ Issoire, France). She has written more than 250 papers, and more than 10 books and monographs.

Marija Radosavljević is an Associate Professor at the Faculty of Economics, University of Nis, for narrow scientific field business management. In 2001, she graduated from the Faculty of Economic in Nis as a student of generation and defended her Master's and doctoral thesis at the Faculty of Economics in Belgrade in 2004 and 2009, respectively. She has participated in few projects, financed by the Ministry of Science of Republic of Serbia. In 2005, 2009 and 2011 she was engaged as a researcher at the University for Economics and Business Administration, Department for Production Management, Wien, Austria and in 2013 as a visiting professor at Willamette University, Atkinson Graduate School of Management, Oregon, the US, as the only candidate from Serbia. Her key interest areas are: quality management, process management, cost management, human resource management. So far, she has published more than 130 papers in journals and proceedings from the conferences (national and international) and 5 monographs. 